\title{
Post-seminal development and morphoanatomy of vegetative and reproductive organs in Stevia rebaudiana (Bert.) Bertoni (Asteraceae)
}

\author{
MÔNICA L. ROSSI ${ }^{1}$, EVERTON H. SOUZA ${ }^{1,2}$, ERIKA M. GRANER ${ }^{3}$, \\ MARCÍLIO DE ALMEIDA ${ }^{3}$ and ADRIANA P. MARTINELLI ${ }^{1}$ \\ ${ }^{1}$ Centro de Energia Nuclear na Agricultura/CENA, Universidade de São Paulo / USP, \\ Av. Centenário, 303, São Dimas, 13416-000 Piracicaba, SP, Brazil \\ ${ }^{2}$ Universidade Federal do Recôncavo da Bahia/UFRB, Rua Rui Barbosa, s/n, Campus \\ de Cruz das Almas, 44380-000 Cruz das Almas, BA, Brazil \\ ${ }^{3}$ Escola Superior de Agricultura "Luiz de Queiroz"/ESALQ, Universidade de \\ São Paulo/USP, Av. Pádua Dias, 11, 13418-900 Piracicaba, SP, Brazil
}

Manuscript received on July 28, 2017; accepted for publication on August 7, 2017

\begin{abstract}
Stevia rebaudiana belongs to the Asteraceae family with high economic and medicinal potential. This article describes and illustrates morphological and histological aspects of leaves and reproductive organs, and the germination process, to provide detailed information on this species and to contribute to taxonomic, phylogenetic and pharmacobotanical projects. The fruit is a cypsela, small, simple, dry, indehiscent, monospermic, light or dark colored, with aristate pappus, and the seed presents a spatulate axile embryo. Germination is phaneroepigeal with a pivotal root system and many absorbing root hairs. The leaves are simple, elliptical to obovate, with two types of trichomes (glandular and tector), with a short petiole, exhibiting an opposite decussate phyllotaxy. Our results showed 37.5\% germination after 12 days, only in the dark cypsela, the light colored being considered unviable. The inflorescence is paniculate and the florets are grouped in capitula with isomorphic ends, monoclinous (bisexual), dichlamydeous, heterochlamydeous, pentamerous calyx and corolla, gamossepalous and gamopetalous. The androecium is gamostemone comprised of five stamens with free filaments, isodynamous and epipetalous stamens, synandrous and rimose anthers. The flower presents an inferior ovary, bicarpelar, unilocular and ovules with a basal placentation. The pollen grains are small, isopolar, radial symmetry, tricolporate, with echinate ornamentation.
\end{abstract}

Key words: anatomy, germination, light microscopy, morphology, scanning electron microscopy.

Correspondence to: Everton Hilo de Souza

E-mail: hilosouza@gmail.com

* Contribution to the centenary of the Brazilian Academy of

Sciences. 


\section{INTRODUCTION}

Stevia rebaudiana (Bert.) Bertoni belongs to the Asteraceae family with an economic importance for its sweetening and medicinal properties. It is a perennial shrub, endemic to Paraguay and Brazil that can reach up to one meter in height and can occur spontaneously in tropical regions, from the Southeastern United States to Argentina (Madan et al. 2010, Gantait et al. 2015).

Stevia leaves contain glycosides, stevioside, steviolbioside, terpenes, rebaudiosides and dulcosides with much higher sweetening power than sucrose and low calories. Stevia extracts have been used as a sugar substitute in many countries (Goettemoeller and Ching 1999). Leaf extracts are also used as diuretics, inulin, antidiabetics, and in the treatment of obesity (Kinghorn 2002, Yadav et al. 2011, Lemus-Mondaca et al. 2012, Gantait et al. 2015, Lopes et al. 2017). Among its by-products are stevia sweetener, widely used as a sugar substitute (Madan et al. 2010, Yadav et al. 2011). Stevia glycosides are the compounds responsible for the sweet taste, and among the 230 species in the genus Stevia, only S. rebaudiana and S. phlebophylla produce steviol glycosides (Brandle and Telmer 2007, Lemus-Mondaca et al. 2012). This sweetener extracted from the leaves can replace conventional dietary sugar and is used in making food products in many countries, including Japan, Brazil, Korea, Israel, United States, Argentina, China, Canada, Paraguay and Indonesia (Gupta et al. 2010, Madan et al. 2010).

Stevia propagation occurs either sexually or asexually. Sexual propagation is difficult due to the short period of seed viability and high production of sterile fruits (Yadav et al. 2011). Goettemoeller and Ching (1999) evaluated the two types of seeds observed (black and tan) in terms of seed viability and germination, observing that dark seeds were heavier and presented significantly higher viability and germination. The reproductive efficiency of a species can be estimated using the seed germination rate (Cury et al. 2010). Because of the low percentage of fertile fruits and low seed longevity, an alternative to increase production is the use of rooted cuttings and micropropagation. Studies have been conducted involving aspects of germination and micropropagation via direct organogenesis and callus formation of $S$. rebaudiana, by Sivaram and Mukundan (2003), Gupta et al. (2010), Razak et al. (2014), among others.

Detailed structural studies are also essential to understand events related to abnormal development of ovular or seminal structures, culminating in seed abortion (Marzineck and Oliveira 2010).

In Asteraceae, the fruit is defined as either an achene or a cypsela, depending on the author. A more detailed study was done by Marzineck et al. (2008), who compared the anatomy of dry, indehiscent and unilocular fruits, evaluating historical antecedents, taking into account the anatomical aspects and fruit ontogeny. According to these authors, a fruit formed from a superior ovary is classified as an achene, whereas a fruit formed from an inferior ovary is classified as a cypsela. Since $S$. rebaudiana has an inferior ovary, we will consider its fruit as a cypsela.

Several studies of this genus and species are found in the literature in different areas, and reviews about its importance and uses can be found in Kinghorn (2002), Madan et al. (2010), and Yadav et al. (2011). However, only a few studies describe detailed anatomical and morphological aspects of $S$. rebaudiana, such as the glandular trichomes (Bondarev et al. 2010, Monteiro et al. 2001), characteristics of leaves and roots (Toma and Zbughin 2005, Reis et al. 2017) from in vitro grown plants and callus (Gupta et al. 2013).

The purpose of this work is to describe aspects of the post-seminal development and morphoanatomy of the leaves and reproductive organs in order to provide information for future taxonomic, phylogenetic and pharmacobotanical 
work involving this species, due to its great economic and medicinal potential.

\section{MATERIALS AND METHODS}

The botanical materials used consisted of leaves and reproductive organs (florets and fruits) of Stevia rebaudiana (Fig. 1a), grown in a greenhouse, at various stages of development.

Seeds were obtained in a greenhouse in plastic pots (13 $\mathrm{cm}$ high by $10 \mathrm{~cm}$ in diameter) with Basaplant ${ }^{\circledR}$ substrate at room temperature and relative humidity of $70 \%$, in Piracicaba, São Paulo, Brazil. One thousand seeds were counted and the number of dark and pale seeds were recorded. For germination studies, seeds were initially separated in dark and pale, using a stereomicroscope. Dark and pale seeds were, separately, immersed in ethanol (70\%) for $5 \mathrm{~min}$, followed by immersion in an aqueous solution of sodium hypochlorite ( $1 \%$ active chlorine), for 20 minutes, and rinsed three times in sterile distilled water. Two hundred and fifty seeds of each type were then placed on two sheets of germitest paper moistened with distilled water, and maintained in clear plastic boxes, 25 seeds per box. The seeds were maintained at 25 $\pm 2{ }^{\circ} \mathrm{C}$ under a 16 -hour photoperiod. In order to check the type of germination, 25 seeds were also germinated in Basaplant ${ }^{\circledR}$ substrate.

To describe the germination and post-seminal development, five replicates were used in the different stages, according to Carneiro (2007) and Cury et al. (2010). A seed was considered germinated when the initial emergence of the radicle (primary root) was observed.

The size of the pappus and cypsela were measured with the aid of a stereomicroscope and digital images. The average of 25 measurements were determined as the mean \pm standard deviation, whereas the germination and post-seminal development analyses were performed using percentage. The morphoanatomical analyses were performed using light microscopy and scanning electron microscopy.

Stomata were quantified in both the abaxial and the adaxial surface using scanning electron microscopy, by counting the number of stomata in 25 squares of $1 \mathrm{~mm}^{2}$, and the results were expressed in number of stomata per square millimeter. The terminology used for pollen grain description follows Punt et al. (2007).

For light microscopy, samples were fixed in a modified Karnovsky (1965) solution (2\% glutaraldehyde; $2 \%$ paraformaldehyde; $5 \mathrm{mM}$ $\mathrm{CaCl}_{2}$ in $0.05 \mathrm{M}$ cacodylate buffer at $\mathrm{pH} 7.2$ ) for 48 hours, dehydrated in an ethyl alcohol series (30\%$100 \% \mathrm{v} / \mathrm{v}$ ) for 6 hours, infiltrated and embedded using the Historesin kit (hydroxymethacrylate, Leica, Heidelberg, Germany). The resin was polymerized at room temperature for 48 hours. Serial histological sections $(4-5 \mu \mathrm{m})$ were obtained with a Leica RM 2155 rotary microtome (Leica, Nussloch, Germany). The sections were placed on histological slides, stained with acid fuchsin ( $1 \%)$, followed by toluidine blue $(0.05 \%)$, covered with synthetic resin (Entellan ${ }^{\circ}$, Merck) and coverslipped. The sections were then analyzed and digital images obtained with an Axioskop 2 photomicroscope (Carl Zeiss, Jena, Germany).

For scanning electron microscopy (SEM), samples were fixed in the same modified Karnovsky solution for 24 hours, dehydrated in an ethanol series (35-100\%). The samples were then critical point dried with liquid $\mathrm{CO}_{2}$, mounted on metal stubs, sputter coated with gold, analyzed under a LEO 435 scanning electron microscope (Carl Zeiss, Jena, Germany) and digital images recorded.

\section{RESULTS AND DISCUSSION}

Stevia rebaudiana cypsela measured $3.03 \pm 0.08$ $\mathrm{mm}$ in length, presenting the seed attached to one point of the pericarp, with a fusiform aspect, linear form and opaque coloration (Fig. 1b). The surface 
presents small globular glands (Fig. 1c), persistent calyx, forming the multiaristate pappus, consisting of a fimbriate corona, with 13-16 bristle-like awns measuring $6.02 \pm 0.89 \mathrm{~mm}$ in length $(\mathrm{n}=25)$, similar to the measurements observed by Macchia et al. (2007), which is approximately twice the size of the cypsela. The cypsela is uniform, golden-yellow and inserted above the floral disk, the carpopodium (gynophore) (Fig. 1b).

According to Ferreira et al. (2001), the pappus in cypselas provides an efficient dispersal mechanism, as well as a classic source of taxonomic information at the genus and species level. However, the pappus reduces the contact between the seeds and the substrate, the rate of water absorption, and consequently the percentage of seed germination (Carneiro and Guedes 1992).

The percentage of dark and pale seeds revealed that only $28 \%$ of these are dark, with $72 \%$ of pale seeds. Yadav et al. (2011) presented in a review that infertile seeds of Stevia are usually pale or clear, while fertile seeds are dark colored.

In our study, germination and postseminal development analyses showed that the germination occurs only in dark cypsela, beginning on the seventh day after the seeds were placed in moistened germitest paper, with $37.5 \%$ of cumulative germination after 12 days. Pale cypsela, which represented $72 \%$ of the 1000 cypsela analyzed, showed no germination, confirming the low efficiency of germination in this species. Similar results were found by Felippe et al. (1971) when cypsela were germinated under controlled light and temperature $\left(25{ }^{\circ} \mathrm{C}\right.$ under continuous light) conditions, these authors reported that germination occurs in only $40 \%$ of the dark cypsela. Furthermore, $S$. rebaudiana is considered genetically self-incompatible and depends on cross-pollination and possibly high levels of hormone precursor substance can influence the formation of viable fruits (Handro and Ferreira 1989). Goettemoeller and Ching (1999) observed considerably higher germination percentage of dark seeds comparing the control (36\%) with different pollination treatments (varying from 68 to $93 \%$ ), including self-pollination $(93 \%)$. The authors suggest a misclassification of seeds in the control, which alerts for the need for an accurate observation under the stereomicroscope. However, self-incompatibility was not confirmed at least for the clones used by these authors.

Morphological aspects of germination were observed during the post-seminal development. Understanding the different stages of seedling development is very important since it allows us to understand their life cycle and provides information for taxonomic, ecological purposes and in the area of seed technology (Pereira et al. 2008).

It was found that the seedlings are phaneroepigeal, with cotyledons rising from the surface of the Basaplant ${ }^{\circledR}$ substrate, exposing the pericarp completely, while the radicle showing positive geotropism develops and forms the primary root. Despite the importance of studies involving the morphology of seedlings, only a few reports present detailed studies on this species, particularly Carneiro (2007), who describes the stages of vegetative and reproductive development of Stevia rebaudiana.

Scanning electron microscopy analysis revealed that the first stage occurs at the fifth day after seeds were placed in the moistured germitest paper. It was characterized by dehiscence of the pericarp, and the cotyledons exposure (Fig. 1c). The second stage takes place on the eighth day, characterized by the emission of the primary root growth at the basal part of the fruit (Fig. 1d).

The roots are short, cylindrical, slender, with many root hairs, which are thin, translucent, irregularly distributed along the primary root, with a noticeable root cap region (Fig. 1d). In general, the primary root is the first structure to extrude the pericarp, fixing the young plant to the substrate and responsible for water and nutrients absorption 
(Gregory 2006). The third stage occurs on the tenth day, with the extrusion of the cotyledons and elongation of the hypocotyl (Fig. 1e). The cotyledons are opposite, semi-open, fleshy, glabrous, sessile, slightly orbiculate, and rounded at the apex, with an entire margin (Fig. 1e). The root system is shown to be pivotal, with absorbent root hairs (Fig. 1f).
Histological analysis of longitudinal sections of the cypselae (fertile dark, and sterile pale) revealed that fertilization occurs in the dark cypselae, with subsequent embryo development, with the endosperm and globular embryo well developed in the seminal cavity (Fig. 1g). In the cotyledonary stage, the embryo is well developed, with spatulate and axial type, with the cotyledons
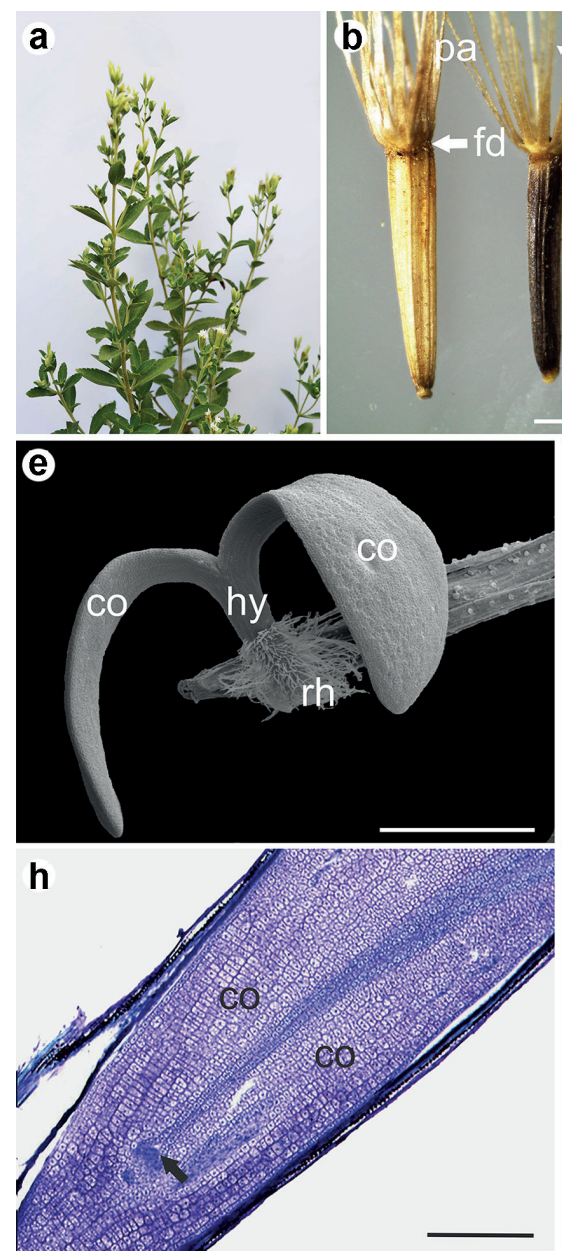
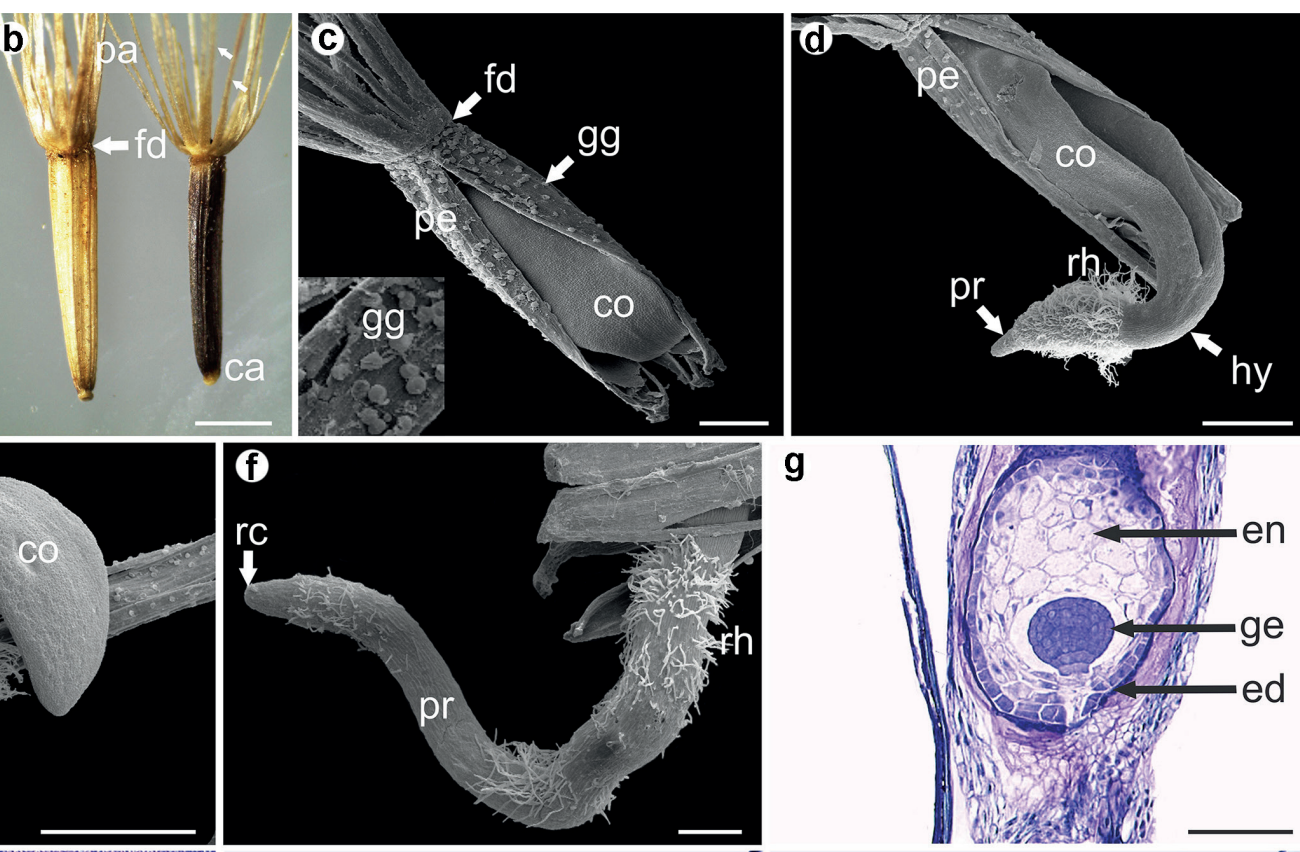

g
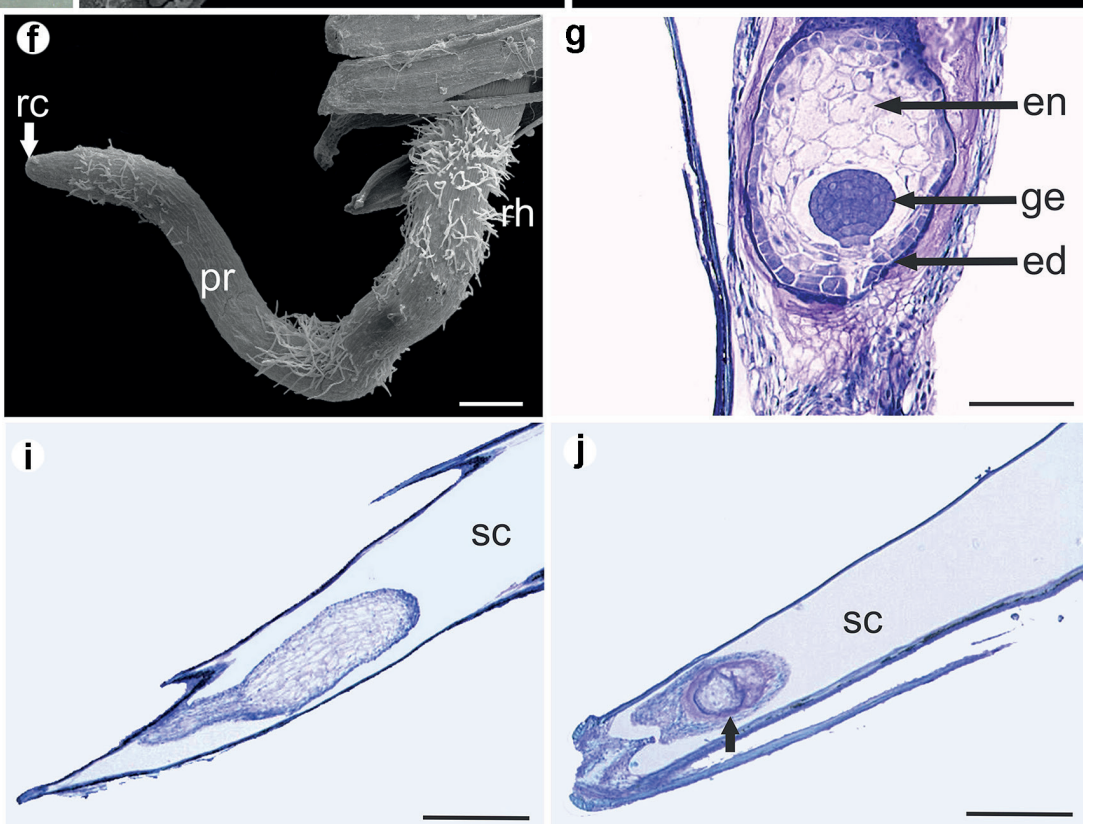

Figure 1 - Post-seminal development morphology of Stevia rebaudiana (Bert.) Bertoni. a) General view of a mature plant with vegetative branches and inflorescences. b) Pale and dark colored mature cypsela showing the floral disc region at the apical part of the pericarp, the pappus with rigid bristle-like awns (arrow), and the carpopodium at the basal region. c-f) Morphological observations under scanning electron microscopy. g-j) Anatomical aspects in light microscopy. c) The rupture of the pericarp, revealing the cotyledons, note the globular glands on the surface of the cypsela. d) Radicle, hypocotyl, and cotyledons emission. e) Development of cotyledons and hypocotyl elongate and shoot apex rising. f) Detail of the primary root, absorbing root-hairs and the root cap. $\mathrm{g}$ ) General view of fertile cypsela with the development of the globular embryo stage, note the nuclear endosperm in the entire seminal cavity. h) The fertile cypsela with the well developed cotyledons, with well-defined shoot apical (arrow). i-j) Sterile cypselas with aborted embryo (arrow in J), and an empty seminal cavity. ca = carpopodium; co = cotyledon; ed = endothelium; en = endosperm; fd = floral disk; $\mathrm{ge}=$ globular embryo; $\mathrm{gg}=$ globular gland; hy = hypocotyl; $\mathrm{pa}=$ pappus; $\mathrm{pe}=$ pericarp; $\mathrm{pr}=$ primary root; $\mathrm{rc}=$ root cap; $\mathrm{rh}=$ root-hairs; $\mathrm{sc}=$ seminal cavity. Bars: $\mathbf{b}=2 \mathrm{~mm} ; \mathbf{c}-\mathbf{e}=500 \mu \mathrm{m} ; \mathbf{f}=300 \mu \mathrm{m} ; \mathbf{g}=50 \mu \mathrm{m} ; \mathbf{h}=200 \mu \mathrm{m} ; \mathbf{i}-\mathbf{j}=500 \mu \mathrm{m}$. 
occupying most of the seminal cavity, with a thin layer of endosperm surrounding the embryo. The cotyledons and embryonic axis showed cells with dense cytoplasm, presence of starch, and well defined root and shoot apical meristems (Fig. 1h). In sterile cypsela embryos did not develop, or developed partially (Fig. 1i).

According to Monteiro (1980) the presence of aborted ovules in sterile pale cypsela, can be explained by a physiological phenomenon of hormonal unbalance that leads to malformed ovules. According to this author, precursors of hormones, such as steviol, can cause this abnormality. It is believed that there may be a discontinuity in pollen tube growth, or a degeneration of the endosperm and the consequent embryo absence. This problem has been subject of discussion among authors, and one possible cause suggested by Marzineck and Oliveira (2010), may be a shortage of reserves resulting in the abortion of ovules and cypsela, considering the large number of flowers in each capitulum.

S. rebaudiana has an opposite decussate leaf insertion pattern (Fig. 1a), although an alternate leaf arrangement has been reported for the genus Stevia (Singh and Rao 2005). The leaves are small, simple, incomplete, due to the absence of the sheath, and present a short petiole (Fig. 2a, b). Therefore, our findings partly disagree with those of Shaffert and Chebotar (1994), who reported that this species presents sessile leaves. The leaf surface can be classified as entire, elliptic to oblanceolate or ovate, serrated margin on the distal half, and entire on the basal half, venation with prominent veins on the abaxial leaf surface, and immersed veins adaxially, except for the midrib, that is prominent in both surfaces, but more evident on the abaxial surface (Fig. 2a-c).

Both epidermis consist of cells with sinuous walls, covered by a thin, smooth cuticle without the presence of epicuticular wax (Fig. 2f). The
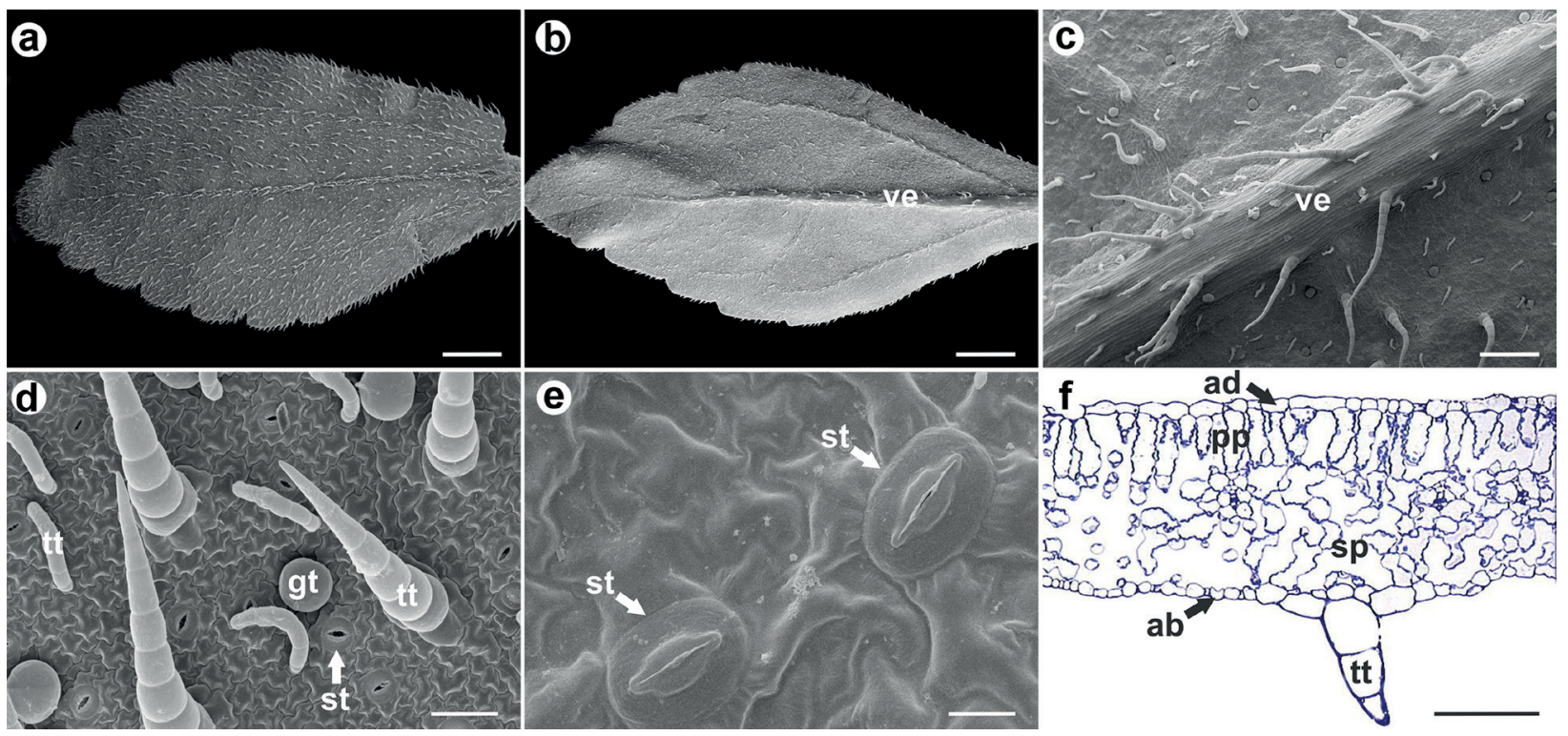

Figure 2 - Leaf morphology of Stevia rebaudiana (Asteraceae). a-e) Morphology observed by scanning electron microscopy. f) Anatomical aspects in light microscopy. a) Leaf adaxial side; b) Leaf abaxial side with prominent venation; c) Detail of the venation on the abaxial leaf surface; d) General view of the three types of trichomes on the abaxial surface; e) Detail of anomocytic stomata. f) Leaf cross section, showing details of the mesophyll and epidermis. ab: abaxial epidermis; ad: adaxial epidermis; gt: glandular trichomes; pp: palisade parenchyma; sp: spongy parenchyma; st: stomata; tt: tector trichomes; ve: venation. Bars: $\mathbf{a}=0.5$ $\mathrm{cm} ; \mathbf{b}=100 \mu \mathrm{m} ; \mathbf{c}=1 \mathrm{~mm} ; \mathbf{d}=200 \mu \mathrm{m} ; \mathbf{e}=10 \mu \mathrm{m} ; \mathbf{f}=100 \mu \mathrm{m}$. 
leaf is dorsiventral, with a unistratified palisade parenchyma on the adaxial surface, and the spongy parenchyma on the abaxial side, consisting of one to two layer of cells, with small intercellular spaces (Fig. 2f).

Glandular trichomes and two types of nonglandular trichomes were observed distributed in the leaf epidermis, with higher numbers in the adaxial side (Fig. 2d). The large non-glandular trichomes are conical, erect, uniseriate, with apical cell relatively elongated, composed of six to ten cells (multicellular), measuring about 250-600 $\mu \mathrm{m}(\mathrm{n}=25)$ (Fig. 2d, f). The smaller non-glandular trichomes are shorter and thinner than the large ones, with three to six cells (uniseriate and multicellular), measuring about 65-80 $\mu \mathrm{m}(\mathrm{n}=25)$ (Fig. 2d).

The glandular trichomes are short, capitate, with an ovoid shape, located in an epidermal depression, with diameters ranging from 40 to $60 \mu \mathrm{m}(\mathrm{n}=25)$. Similar results were observed in $S$. rebaudiana by Bondarev et al. (2010). Although the trichomes can vary in their structure in larger or smaller groups of plants, these can be used for taxonomic purposes (Evert 2006). Several functions can be assigned in common to these types of trichomes (glandular and non-glandular) as a contribution to the regulation of plant temperature and light reflection barrier to movement of insects on the surface, reducing water loss, among others (Empinotti and Duarte 2008). Furthermore, some types of trichomes can secrete compounds with biological activities, including secondary metabolites, which function to protect plants against herbivores and pathogens, of great interest to the pharmaceutical, cosmetic and fragrance industries, or the use as a natural pesticide (Werker 1993). Taleb-Contini et al. (2007) studying trichomes of species of the genus Chromolaena (Eupatorieae, Asteraceae) identified 12 flavonoids through high performance liquid-chromatography. It is noteworthy that flavonoids may have different activities such as antioxidant, anti-inflammatory, antimicrobial, antiprotozoal, vascular activities, among other medicinal properties (Ogundipe et al. 2001, Xu and Lee 2001, Taleb-Contini et al. 2007).

In S. rebaudiana, Monteiro et al. (2001) demonstrated that the secretory material accumulated in the trichome cavity is mostly of a lipophilic nature, while some are hydrophilic. The authors emphasized, however, that the results from a detailed chemical study of the secretory material, and observations on plants growing in their natural habitat, can give the investigators a solid basis for speculations about the real function(s) of such trichomes.

The structural organization of the leaves in our study revealed stomata in both surfaces with predominance in the abaxial surface, characterizing a hypostomatic leaf. Stomata averaged a density of $204.19 \mathrm{~mm}^{-2}$ on the abaxial surface, and 73.11 $\mathrm{mm}^{-2}$ on the adaxial surface, these are in the same level or slightly above the epidermis, with anomocytic stomata randomly distributed on the surface (Fig. 2e). Similar characteristics have been observed in other medicinal Asteraceae species such as Vernonia condensata (Lolis and MilanezeGutierre 2003), Calea uniflora (Budel et al. 2006), Acanthospermum australe (Martins et al. 2006) and Elephantopus mollis (Empinotti and Duarte 2008).

The florets are grouped in terminal or axillary capitula, with five to six small, sessile florets $(15.52 \pm 0.53 \mathrm{~mm})(\mathrm{n}=25)$, on a flat receptacle, surrounded by involucral bracts arranged in indeterminate heads, monoclinous, dichlamydeous, heterochlamydeous (Fig. 3a, b). The callyx is highly modified to form the pappus: the petals are gamopetalous, tubular and pentamerous, with actinomorphic symmetry. The androecium is pentamerous (isostemone), gamostemone, stamens present a free filament, conate and homodynamous anthers (Fig. 3a-c). Disk florets present the pappus, petals, and internally oval-shaped nectaries with small densely cytoplasmic cells (Fig. 3h-j).

The anthers form a tube with rimose dehiscence in which the pollen grains are released 

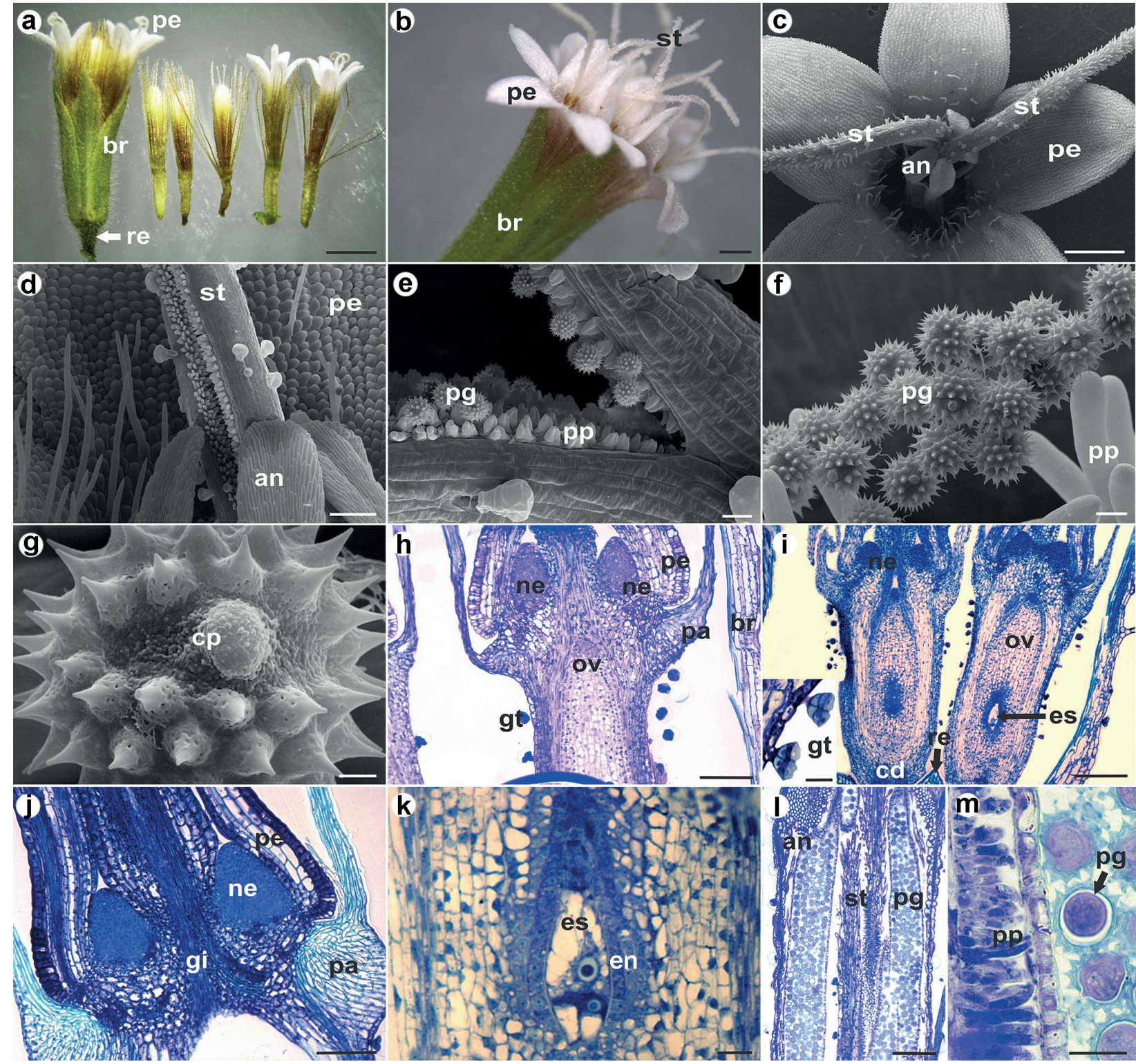

Figure 3 - Floral morphology of Stevia rebaudiana (Asteraceae). a-b) General view of capitula with florets in different stages of development. c-g) Morphological studies under scanning electron microscopy. h-l) Anatomical aspects observed under light microscopy. c) Floret details showing the pentamerous corolla, connate anthers and stigma branches; d) Detail of petals, anthers and stigma; e-f) Stigmatic surface with pollen grains adhered to the papillae; g) Pollen grain showing the colpore region and spines with perforated base; $\mathbf{h}$ ) The distal region of the ovary, with the pappus insertion, petals, and nectaries; i) General aspect of the unilocular ovary and carpopodium, with a detail of glandular trichomes on the ovary wall epidermis; $\mathbf{j}$ ) Detail of the nectaries, petals, and pappus insertion. k) Detail of the embryo sac and endothelium; l) Anthers filled with pollen grains and the stigma branches in the center; m) a detail of papillae and pollen grains (arrow). an: anther; br: bract; br: involuncral bracts; cd: carpopodium; cp: colpore; en: endothelium; es: embryo sac; gi: ginophore; gt: glandular trichome; ne: nectary; ov: ovary; pa: pappus; pe: petal; pg: pollen grain; pp: papillae; re: receptacle; st: stigma. Bars: $\mathbf{a}=0.5 \mathrm{~cm} ; \mathbf{b}, \mathbf{h}=100 \mu \mathrm{m} ; \mathbf{c}=20 \mu \mathrm{m} ; \mathbf{d}, \mathbf{f}=10 \mu \mathrm{m} ; \mathbf{e}, \mathbf{m}=20 \mu \mathrm{m} ; \mathbf{g}=2 \mu \mathrm{m} ; \mathbf{i}$, $\mathbf{j}, \mathbf{l}=200 \mu \mathrm{m}($ detail $=25 \mu \mathrm{m}) ; \mathbf{k}=50 \mu \mathrm{m}$. 
and subsequently pushed out, due to the growth of the style, which emerge in the center of the floral meristem. At anthesis, the stigma presents two branches from the middle and style is surrounded by the anthers (Fig. 3c, d). The two stigma branches curve outwards, exposing the stigmatic surface with numerous papillary cells for pollen contact (Fig. 3e, f).

The pollen grains are prolate spheroidal $(\mathrm{P} / \mathrm{E}$ $=1.03)$, small $(21.50 \pm 0.21 \mu \mathrm{m})(\mathrm{n}=25)$, isopolar, radially symmetric, tricolporate with a distinct circular pore surrounded by spines generally presenting a granulate membrane and elongate endoaperture. The sexine has spines with echinate ornamentation, being tected with a wide base having perforations in the base and a rounded apex (arrows) (Fig. 3f, g). Asteraceae family is characterized as stenopalynous, presenting distinctive characteristics, always near to spherical shape, mostly tricolporate, are also some of the characteristics observed by Cancelli et al. (2006) who studied the pollen morphology of species of Asteraceae family.

Stevia floret is epigynous, with a concave receptacle that supports the ovary, so that the other flower whorls and the nectaries develop on the receptacle on the distal part of the ovary, constituting the hypanthium (Figs. 3a, h, i). The gynoecium is syncarpous, bicarpelar and unilocular, with basal placentation. Biseriate, multicellular glandular trichomes differentiate in the uniseriate epidermis of the ovary (detail in Fig. 3i). These results are similar to the descriptions made by Galastri and Oliveira (2010), which studied the ontogeny of the fruit and seed of Vernonia platensis, Julio and Oliveira (2009) in Bidens pilosa and B. gardineri, and Marzineck and Oliveira (2010) in six species of the Asteraceae family, all of these features found in the studied species corroborate the literature available for the family.

At the distal region of the hypanthium, the double pappus is inserted, composed of bristles.
At the proximal region, the florets develop on the carpopodium, the receptacle in which the florets are attached to the inflorescence. The endothelium is related to nutrition and may be responsible for the transfer of nutrients from the seed coat to megagametophyte, accumulation of nutrients, secretion of digestive enzymes, and as a barrier that delimits the growth of the embryo (Werker 1997).

The morphoanatomical description of floral structures and post-seminal development in Stevia rebaudiana presented here include new details regarding the botanical description and taxonomy of this important species and can contribute to a better knowledge of the evolution of morphological characters in Asteraceae.

\section{ACKNOWLEDGMENTS}

The authors would like to thank Coordenação de Aperfeiçoamento de Pessoal de Nível Superior (PROCAD - 2013; CAPES-Embrapa), Núcleo de Apoio à Pesquisa em Microscopia Eletrônica Aplicada à Agricultura (NAP/MEPA/Esalq/USP) for the use of the scanning electron microscope, and Dr. Oscar Fontão de Lima Filho, Embrapa Agropecuária Oeste, for providing seeds for this work.

\section{REFERENCES}

BONDAREV NI, SUKAHANOVA MA, SEMENOVA GA, GORYAEVA OV, ANDREEVA SE AND NOSOV AM. 2010. Morphology and Ultrastructure of trichomes of intact and in vitro plants of Stevia rebaudiana Bertoni with reference to biosynthesis and accumulation of steviol glycosides. Moscow U Biol Sci Bull 65: 12-16.

BRANDLE J AND TELMER P. 2007. Steviol glycoside biosynthesis. Phytochemistry 68: 1855-1863.

BUDEL JM, DUARTE MR, FARAGO PV AND TAKEDA IJM. 2006. Caracteres anatômicos de folha e caule de Calea uniflora Less., Asteraceae. Rev Bras Farmaco 16: 53-60.

CANCELLI RR, SCHNEIDER AA AND BAUERMANN SG. 2006. Morfologia polínica do gênero Pluchea cass. (Asteraceae), no Rio Grande do Sul, Brasil. Rev Bras Paleontol 9: 149-156. 
CARNEIRO JWP. 2007. Stevia rebaudiana (Bert.) Bertoni: stages of plant development. Can J Plant Sci 87: 861-865.

CARNEIRO JWP AND GUEDES TA. 1992. Influência do posicionamento das sementes de Stevia (Stevia rebaudiana (Bert.) Bertoni) no substrato avaliada pela função de distribuição de Weibull. Rev Bras Sem 14: 65-68.

CURY G, NOVEMBRE ADL AND GLÓRIA BA. 2010. Seed germination of Chresta sphaerocephala DC. and Lessingianthus bardanoides (Less.) H. Rob. (Asteraceae) from cerrado. Braz Arch Biol Techn 53: 1299-1308.

EMPINOTTI CBA AND DUARTE MR. 2008. Estudo anatômico de folha e caule de Elephantopus mollis Kunth (Asteraceae). Rev Bras Farmaco 18: 108-116.

EVERT RF. 2006. Esau's Plant anatomy: meristems, cells, and tissues of the plant body: their structure, function, and development, $3^{\text {rd }}$ ed., Madison: Wiley-Interscience, $601 \mathrm{p}$.

FELIPPE GM, LUCAS NMC, BEHAR L AND OLIVEIRA MAC. 1971. Observações a respeito da germinação de Stevia rebaudiana Bert. Hohenea 1: 83-93.

FERREIRA AG, CASSOL B, ROSA SGT, SILVEIRA TS, STIVAL AL AND SILVA AA. 2001. Germinação de sementes de Asteraceae nativas no Rio Grande do Sul, Brasil. Acta Bot Bras 15: 231-242.

GALASTRI NA AND OLIVEIRA DMT. 2010. Morfoanatomia e ontogênese do fruto e semente de Vernonia platensis (Spreng.) Less. (Asteraceae). Acta Bot Bras 24: 73-83.

GANTAIT S, DAS A AND MANDAL N. 2015. Stevia: a comprehensive review on ethnopharmacological properties and in vitro regeneration. Sugar Technol 17: 95-106.

GOETTEMOELLER J AND CHING A. 1999. Seed germination in Stevia rebaudiana. In: Janick J (Ed), Perspectives on new crops and new uses. Alexandria, ASHS Press, p. 510-511.

GREGORY PJ. 2006. Plant Roots: Growth, activity and interaction with soils. Oxford, Blackwell Publishing, 318 p.

GUPTA E, PURWAR S, SUNDARAM S AND RAI G. 2013. Nutritional and therapeutic values of Stevia rebaudiana: A review. J Med Plant Res 7: 3343-3353.

GUPTA P, SHARMA S AND SANJAY S. 2010. Callusing in Stevia rebaudiana (natural sweetener) for steviol glycoside production. Int J Agric Biol Sci 1: 571-576.

HANDRO W AND FERREIRA CM. 1989. Stevia rebaudiana (Bert.) Bertoni: Production of natural sweeteners. Biotechnol Agric Forest 7: 468-487.

JULIO PGS AND OLIVEIRA DMT. 2009. Morfoanatomia comparada e ontogênese do pericarpo de Bidens gardneri Baker e B. pilosa L. (Asteraceae). Braz J Bot 32: 109-116.

KARNOVSKY MJ. 1965. A formaldehyde-glutaraldehyde fixative in high osmolality for use in electron microscopy. J Cell Biol 27: 137-138A.

KINGHORN AD. 2002. Stevia: The genus Stevia. London, New York, Taylor \& Francis, 224 p.
LEMUS-MONDACA R, VEGA-GÁLVEZ A, ZURABRAVO L AND AH-HEN K. 2012. Stevia rebaudiana Bertoni, source of a high-potency natural sweetener: A comprehensive review on the biochemical, nutritional and functional aspects. Food Chem 132: 1121-1132.

LOLIS MIGA AND MILANEZE-GUTIERRE MA. 2003. Morfoanatomia das folhas de Vernonia condensata Baker (Asteraceae), o "figatil". Rev Bras Farmaco 13: 68-71.

LOPES SMS, KRAUSOVÁ G, CARNEIRO JWP, GONÇALVES JE, GONÇALVES RAC AND OLIVEIRA AJB. 2017. A new natural source for obtainment of inulin and fructo-oligosaccharides from industrial waste of Stevia rebaudiana Bertoni. Food Chem 225: 154-161.

MACCHIA M, ANDOLFI L, CECCARINI L AND ANGELINI LG. 2007. Effects of temperature, light and pre-chilling on seed germination of Stevia rebaudiana (Bertoni) Bertoni accessions. Ital J Agron 2: 55-62.

MADAN S, AHMAD S, SINGH GN, KOHLI C, KUMAR Y, SING R AND GARG M 2010. Stevia rabaudiana (Bet.) Bertoni - A Review. Indian J Nat Prod Resourc 1: 267-286.

MARTINS LRR, MOURÃO KSM, ALBIEIRO ALM, CORTEZ DAG, DIAS-FILHO BP AND NAKAMURA CV. 2006. Estudo morfoanatômico preliminar do caule e da folha de Acanthospermum australe (Loefl.) Kuntze (Asteraceae - Heliantheae). Rev Bras Farmaco 16: 42-51.

MARZINECK J, DE-PAULA OC AND OLIVEIRA DMT. 2008. Cypsela or achene: Refining terminology by considering anatomical and historical factors. Braz J Bot 31: 549-553.

MARZINECK J AND OLIVEIRA DMT. 2010. Structure and ontogeny of the pericarp of six Eupatorieae (Asteraceae) with ecological and taxonomic considerations. An Acad Bras Cienc 82: 279-291.

MONTEIRO R. 1980. Taxonomia e biologia da reprodução de Stevia rebaudiana Bert., 104 p. Dissertação de Mestrado. Universidade Estadual de Campinas, Campinas. (Unpublished).

MONTEIRO WR, CASTRO MM, MAZZONI-VIVEIROS SC AND MAHLBERG GPG. 2001. Development and some histochemical aspects of foliar glandular trichomes of Stevia rebaudiana (Bert.) Bert. - Asteraceae. Braz J Bot 24: 349-357.

OGUNDIPE OO, MOODY JO, HOUGHTON PJ AND ODELOLA HA. 2001. Bioactive chemical constituents from Alchornea laxiflora (Benth) Pax and Hoffman. J Ethnopharmacology 74: 275-280.

PEREIRA AR, PEREIRA TS, RODRIGUES AS AND ANDRADE ACS. 2008. Morfologia de sementes e do desenvolvimento pós-seminal de espécies de Bromeliaceae. Acta Bot Bras 22: 1150-1162.

PUNT W, HOEN PP, BLACKMORE S, NILSSON S AND LE THOMAS A. 2007. Glossary of pollen and spore terminology. Rev Palaeobot Palyno 143: 1-8. 
RAZAK UNAA, ONG CB, YU TS AND LAU LK. 2014. In vitro micropropagation of Stevia rebaudiana Bertoni in Malaysia. Braz Arch Biol Techn 57: 23-28.

REIS RV, CHIERRITO TPC, SILVA TFO, ALBIERO ALM, SOUZA LA, GONÇALVES JE, OLIVEIRA AJB AND GONÇALVES RAC. 2017. Morpho-anatomical study of Stevia rebaudiana roots grown in vitro and in vivo. Braz $\mathrm{J}$ Pharm 27: 34-39.

SHAFFERT EE AND CHEBOTAR AA. 1994. Structure, topography and ontogeny of Stevia rebaudiana. Bot Zhurnal 79: 38-48.

SINGH SD AND RAO GP. 2005. Stevia: The herbal sugar of the $21^{\text {st }}$ century. Sugar Tech 7: 17-24.

SIVARAM L AND MUKUNDAN U. 2003. In vitro culture studies on Stevia rebaudiana. In Vitro Cell Dev B-Pl 39: 520-523.

TALEB-CONTINI DH, SCHORR K, COSTA FB AND OLIVEIRA DCR. 2007. Detection of flavonoids in glandular trichomes of Chromolaena species (Eupatorieae,
Asteraceae) by reversed-phase high-performance liquid chromatography. Braz J Pharm Sci 43: 315-321.

TOMA I AND ZBUGHIN G. 2005. Histo-anatomical aspects of aerial vegetative organs of Stevia rebaudiana Bertoni cultivated in vitro (ii) Analele ştiinţifice ale Universităţii “Al. I. Cuza” Iaşi Tomul LI, s. II a. Biologie vegetală, p. 29-38.

WERKER E. 1993. Function of essential oil secreting glandular hairs in aromatic plants of the Lamiaceae - a review. Flavour Frag J 8: 249-255.

WERKER E. 1997. Seed anatomy. Berlin, Gebrüder Borntraeger, $424 \mathrm{p}$.

XU HX AND LEE SF. 2001. Activity of plant flavonoids against antibiotic-resistant bacteria. Phytother Res 15: 3943.

YADAV AK, SINGH S, DHYANI D AND AHUJA S. 2011. A review on the improvement of stevia [Stevia rebaudiana (Bertoni)]. Can J Plant Sci 91: 1-27. 